\title{
Subklinik Mastitisli İneklerde Süt ve Süt Hücrelerinde Vitamin C Düzeyleri
}

\author{
Pınar Peker Akalın', Yaşar Ergün², Nuri Başpınar³,Gökhan Doğruer², \\ Altuğ Küçükgül ${ }^{1}$, Zafer Cantekin ${ }^{4}$, Mustafa İşgör ${ }^{1}$, Mustafa Sarıbay ${ }^{2}$, \\ Ayhan Baştan ${ }^{5}$, Ece Koldaş², Seçkin Salar ${ }^{5}$, İshak Gökçek ${ }^{6}$ \\ Geliş Tarihi / Received: 20.05.2016, Kabul Tarihi / Accepted: 03.06.2016
}

\author{
${ }^{1}$ Mustafa Kemal Üniversitesi Veteriner Fakültesi Biyokimya Anabilim Dall, Hatay \\ ${ }^{2}$ Mustafa Kemal Üniversitesi Veteriner Fakültesi Doğum ve Jinekoloji Anabilim Dal, , Hatay \\ ${ }^{3}$ Selçuk Üniversitesi Veteriner Fakültesi Biyokimya Anabilim Dall, Konya \\ ${ }^{4}$ Mustafa Kemal Üniversitesi Veteriner Fakültesi Mikrobiyoloji Anabilim Dal, Hatay \\ ${ }^{5}$ Ankara Üniversitesi Veteriner Fakültesi Doğum ve Jinekoloji Anabilim Dall, Ankara \\ ${ }^{6}$ Mustafa Kemal Üniversitesi Veteriner Fakültesi Fizyoloji Anabilim Dalı, Hatay
}

\begin{abstract}
Özet: Çalışma, subklinik mastitisli ineklerde süt ve süt hücrelerinde Vitamin C düzeylerinin belirlenmesi amacıyla yapılmıştır. Süt örneklerinde somatik hücre sayımı yapıldı ve örnekler kontrol (1-87 x 1000 hücre), mastitli 1. grup (154-380 x 1000 hücre), 2. grup (418-812 x 1000 hücre), 3. grup (914-1928 x 1000 hücre) ve 4. grup (2614-8050 x 1000 hücre) olacak şekilde gruplandırıldı $(\mathrm{n}=12)$. Süt hücrelerinde ve süt serumunda (yağı ve hücreleri alınmış) Vitamin $\mathrm{C}$ düzeyleri belirlendi ve Vitamin C ve süt somatik hücre sayısı arasındaki korelasyonlar hesaplandı. Ayrıca alınan süt numunelerinden mikrobiyolojik ekim yapılarak, etken izolasyonu ve identifikasyonu yapıldı. Subklinik mastitisli sütlerde $\left(1,2,3\right.$, ve 4. gruplar) $\mu \mathrm{g} / 10^{6}$ hücredeki Vitamin $\mathrm{C}$ düzeyleri kontrol grubundan düşük olarak bulunurken $(\mathrm{p}<0,001)$, süt hücresi Vitamin C düzeyleri ile süt somatik hücre sayısı arasında pozitif bir korelasyon belirlendi $(r=0,469, p<0,001$ $\mathrm{n}=60$ ). Süt serumu sonuçları ele alındığında mastitli 4. grup Vitamin $C$ düzeyleri diğer mastit gruplarına $(\mathrm{p}<0,05)$ ve kontrol grubuna $(\mathrm{p}>0,05)$ göre düşük olduğu görüldü. Ayrıca süt serumu Vitamin $\mathrm{C}$ düzeyleri ile süt somatik hücreleri arasında negatif bir korelasyon saptand $(r=-0,420, p<0,01 n=60)$. Sonuç olarak subklinik mastitisin derecesi ile ilgili olarak somatik hücre sayısının arttığı, süt serumu Vitamin $\mathrm{C}$ düzeylerinin düştüğü, birim hücre başına düşen Vitamin $\mathrm{C}$ düzeylerinin azaldığı, Vitamin C düzeyleri ile mastit arasında bir bağıntının olduğu belirlendi.
\end{abstract}

Anahtar kelimeler: Subklinik mastitis, Vitamin C, Süt Somatik Hücre Sayısı, İdentifikasyon

\section{Effects of Subclinical Mastitis on Milk Somatic Cells and Milk Vitamin C Levels in Cows}

\begin{abstract}
In this study, it was aimed to determine the levels of Vit $\mathrm{C}$ in milk and milk cells of subclinical mastitic cows. Somatic cell count was determined in the quarter milk samples of all animals and the groups were scored control (1-87 x 1000 cells), mastitic $1^{\text {st }}$ group (154-380 x 1000 cells), $2^{\text {nd }}$ group (418-812 x 1000 cells), $3^{\text {rd }}$ group (914-1928 x 1000 cells) and $5^{\text {th }}$ group (2614-8050 x 1000 cells) $(\mathrm{n}=12)$. Milk serum and milk cell Vitamin C levels were determined and the correlation between Vitamin $\mathrm{C}$ levels and somatic cell count were evaluated. Also microbiological diagnosis was conducted. In subclinical mastitic milks, Vitamin C levels $\left(\mu \mathrm{g} / 10^{6}\right.$ cell) were lower compared to control group ( $\left.\mathrm{p}<0,001\right)$ and positive correlation was determined between milk cell Vitamin $\mathrm{C}$ levels and somatic cell count $(\mathrm{r}=0,469, \mathrm{p}<0,001$ $\mathrm{n}=60$ ). As regards milk serum, Vitamin $\mathrm{C}$ levels were lower in the 5 th group compared to the other mastitic $(\mathrm{p}<0,05)$ and control groups $(\mathrm{p}>0,05)$. There was a negative correlation between milk serum Vitamin $\mathrm{C}$ levels and somatic cell count $(r=-0,420, p<0,01 n=60)$. In conclusion, it was found that somatic cell count was elevated with the mastitis levels, gradually, Vitamin $\mathrm{C}$ levels per cell and in milk serum decreased in mastitis. It is also found that there was a correlation between Vitamin C levels and mastitis.
\end{abstract}

Key words: Sublinical Mastitis, Vitamin C, Somatic Cell Count, Identification

\section{Giriş}

Mastitis hayvan sağlığını tehdit etmesinin yanı sira ciddi ekonomik kayılara neden olan ve insan sağlığ1 ve beslenmesi açısından da önemli olan bir problemdir. Mastitis sütteki fiziksel, kimyasal ve bakteriyolojik değişimlerle meme glandular dokusundaki patolojik değişimleri kapsar [19]. Klinik mastitis olgularında süt ve meme dokusunda önemli yangısal belirtiler görülürken, subklinik mastitiste gözle görülür değişiklikler oluşmamaktadır. Bu nedenle subklinik mastitis uzun süre ve daha yaygın 
bir șekilde devam etmekte ve daha fazla ekonomik kayıplara neden olmaktadır [4].

Subklinik mastitis görülme sıklığ 1 Türkiye'de \%30 olarak belirlenmiş, görülme sıklığının bölgelere göre farklılık gösterdiği bildirilmiştir; Kars yöresinde yapılan çalışmada bu oran \%15.78 iken, Afyon ilinde \% 43.7, Konya yöresinde \%23, Hatay ilinde $\% 48$ ile $\% 71$, Cukurova bölgesinde $\% 58$ olarak bildirilmiştir [13]. Ayrıca kooperatifler bünyesindeki işletmelerde bu oranların, büyük işletmelere göre daha yüksek olduğu (\% 61.3 inek, \% 26.7 meme lobu) da bildirilmiştir [23]. Bu durum; bölgenin sıcaklık ve nem oranının yüksek olmasından kaynaklanabildiği gibi, sağım ve altlık yönetiminden de direkt olarak etkilenmektedir [28].

Somatik hücreler meme dokusundan süte kar1şan epitel hücreleri ve yang1 veya travma durumlarında kandan meme bezine geçen lökositlerden oluşmaktadır. Süt somatik hücrelerinin $\% 75^{\prime}$ 'ini lökositler (lenfosit, nötrofil ve makrofaj) \%25'ini de epitel hücreleri oluşturur [19]. Meme dokusu enfeksiyonlarında sütteki lökosit ve epitel hücre sayıları artar [4]. Sağlıklı meme somatik hücre sayıs1 100.000 hücre/ml'den az kabul edilirken [18], meme içi enfeksiyon geliştiğinde enfeksiyona karŞ1 artan immun yanıta paralel olarak lökosit sayısı (özellikle nötrofiller) önemli ölçüde artar. Bu say1nın, California Mastitis Test (CMT) şüpheli olanlarda 150.000-500.000, CMT (+) olanlarda 400.0001.500.000, CMT $(++)$ olanlarda 800.000-5.000.000 ve CMT $(+++)$ olanlarda ise 5.000 .000 'dan fazla sayida olduğu bildirilmektedir $[1,4,5]$.

Yang1 sirasında lökositlerde meydana gelen artış, mikroorganizmalara karşı vücudun savunma sistemlerinden birini oluşturmakta ve serbest radikal üretimini artırmaktadır. Serbest radikal eşlenmemiş elektron taşıyan atom veya atom gruplarıdır. $\mathrm{Bu}$ moleküllerin artması sonucu meydana gelen oksidatif hasara bağlı olarak, membran bütünlüğünün bozulduğu, DNA hasarlarının olduğu proteinlerin yapı ve fonksiyonlarının değiştiği bildirilmektedir [16]. Serbest radikallerin zararlı etkilerine karşı organizmada antioksidan olarak ifade edilen koruyucu mekanizmalar vardır. Bu koruyucu mekanizmaların bir kısmı serbest radikal oluşumunu önlerken, bir kısmı ise oluşmuş serbest radikallerin zararlı etkilerini önlemektedir. Artan serbest radikaller ve mevcut antioksidan moleküller arasındaki dengesizlik oksidatif strese sebep olmaktadır [11]. Serbest radikallerin zararlı etkilerinden korunmak için hücreler enzimatik ve nonenzimatik antioksidan savunma sistemlerini kullanırlar. Bunlar başlıca; superoksid dismutaz, glutatyon peroksidaz, katalaz gibi enzimatik ve glutatyon, $\alpha$-tokoferol, karotenoidler ve Vitamin C (Vit C) gibi enzimatik olmayan moleküllerdir [11, 20]. Eschericia coli ile deneysel olarak enfekte edilen Holstein ineklerde 24 saat sonra alınan süt örneklerinde Vit $\mathrm{C}$ düzeylerinin mastitis derecesinin artması ile birlikte önemli düzeyde düştüğü bildirilmiștir [25]. Develerde de mastitisli sütlerdeki Vit $\mathrm{C}$ düzeyleri sağlıklılara göre daha düşük olarak belirlenmiştir [12]. Yapılan araştırmalarda; antioksidanlar düzeyinde meydana gelen azalmanın mastitis riskini arttırabileceği ve antioksidan takviyesinin ise bunun önlenmesinde etkili olabileceği belirtilmektedir [21, 22].

Subklinik mastitis oluşumunda rol oynayan patojenler kontagiyöz ( $S$. aureus, $S$. agalactia ve $S$. bovis) ve çevresel (E. coli, P. aeruginosa, $S$. uberis, $S$. chromogenes ve diğer koagulaz negatif stafilokoklar) olarak sinıflandırılmaktadır. Son yıllarda dünyada subklinik mastitis etkenleri arasında koagulaz negatif stafilokolar (KNS) ilgi çekmektedir. KNS'ler subklinik mastitise neden olduğundan son yıllarda birçok ülkede subklinik mastitisin önemli etkenlerinden biri olarak kabul edilmektedir [2].

Sunulan çalışmada farklı derecelerde subklinik mastitisli sütlerde (yağı ve hücreleri alınmış) ve hücrelerinde Vit $\mathrm{C}$ düzeylerinin belirlenmesi, Vit $\mathrm{C}$ ve somatik hücre sayısı arasındaki olası korelasyonun incelenmesi amaçland. Ayrıca mastitis etkenlerinin tespiti yapılarak patojenler ile Vit $\mathrm{C}$ düzeyleri arasındaki bağıntı incelendi.

\section{Materyal ve Metod}

\section{Materyal}

Laktasyonun aynı döneminde olan 4-5 yaș aralığındaki Holstein 1rkı inekler çalışmanın hayvan materyalini oluşturdu. Meme başı temizlenip \%70'lik alkol ile silindikten sonra ilk sıkım süt atılarak her bir meme lobundan 45-50'şer ml süt örnekleri alındı. İneklerin her bir meme lobundan alınan süt örnekleri California Mastitis Test (CMT) ile muayene edilerek, CMT reaksiyonlarına (- negatif, -/+ şüpheli, $+1,+2,+3)$ göre gruplandırıld. 


\section{Metot}

\section{Somatik Hücre Sayımı}

Çalışmada subjektif [9] bir metod olan CMT skorlamasına göre alınan süt örneklerinde somatik hücre sayımı yapıld1 ve yeniden yapilan skorlamada örnekler, kontrol (1-87 x 1000 hücre), mastitli 1 . grup (154-380 x 1000 hücre), 2. grup (418-812 x 1000 hücre), 3. grup (914-1928 x 1000 hücre) ve 4. grup (2614-8050 x 1000 hücre) olarak gruplandırıldı $(\mathrm{n}=12)$. Alınan süt örneklerine, hücreleri koruma amaçli, $0.05 \mathrm{ml} \mathrm{\% 24} \mathrm{mg} \mathrm{sodyum} \mathrm{azid}$ (Sigma-Aldrich) eklendi. Somatik hücre sayımı yar1-otomatik bir cihaz olan ve flowsitometri prensibi ile çalışan Bentley BactoCount IBCm (Bentley Instruments Inc.,Chaska, MN, USA) ile gerçekleştirildi.

\section{Biyokimyasal Analizler}

Biyokimya laboratuvarına getirilen sütler, süt serumu ve süt hücrelerinin ayrımlanması için $600 \mathrm{~g}$ 'de $4^{\circ} \mathrm{C}$ 'de $10 \mathrm{dk}$. santrifüj edildi. Santrifüj sonrası üstteki yağ tabakası koton bir aparat ile alınarak, yağ 1 ve hücreleri uzaklaştırılan, süpernatant (süt serumu) eppendorf tüplere aktarıldı, Vit C analizi için, üzerine $\% 6$ 'lık Triklor asetik asit (TCA, 1 birim serum +2 birim TCA) eklenerek analizler için $-86^{\circ} \mathrm{C}$ soğutucuda sakland1. Santrifüj sonrasi dipteki pellet, soğuk PBS ile 2 defa yıkandi. Her yıkama sonrasında 600 g'de $4^{\circ} \mathrm{C}^{\prime}$ de $10 \mathrm{dk}$ santrifüj edildi. Yıkanmış hücre pelleti PBS ile 2 ml'ye tamamlandi. Hücreler 10 sn süreli, 30 sn soğutmalı, 5 tekrarlı olacak şekilde sonike edildi (Bandelin, Sonopuls, HD 2070, Almanya). Sonikasyon sonrasinda homojenatlar 13000 g' de $4^{\circ} \mathrm{C}$ 'de $15 \mathrm{dk}$ santrifüj edildi. Hücre homojenizasyon süpernatantları, üzerine $\% 6$ 'lık triklor asetik asit (TCA, 1 birim serum +2 birim TCA) eklenerek, analizler için $-86^{\circ} \mathrm{C}$ soğutucuda sakland1. Analizden hemen önce süt serumu ve hücre homojenizasyon süpernatantları çözündürüldü ve 1000 g'de $4^{\circ} \mathrm{C}^{\prime}$ de $15 \mathrm{dk}$ santrifüj edildi. Süpernatantlarda Vit $\mathrm{C}$ analizi yapıldi.

\section{Vitamin C Analizi}

Süt serumu ve hücre süpernatantlarında Vit C analizi Haag [5]'ın metoduna göre yapıldı: Askorbik asit hafif oksitleyici etkenlerle dehidro askorbikasite dönüşür, dehidro askorbik asit hafif asit solüsyonlarda yavaş bir şekilde diketogulonikasite dönüşür.
Dehidro askorbik asit ve diketogulonik asit, 2,4-dinitrofenilhidrazin (DNPH) ile reaksiyona girerek bis 2,4-dinitrofenilhidrazonu oluşturur. Sonuçlar $\mu \mathrm{g} / \mathrm{ml}$ ve $\mu \mathrm{g} / 10^{6}$ hücre olarak verildi.

\section{Mikrobiyolojik Muayene}

Laboratuvara getirilen süt numuneleri öncelikle bakteriyoskopi amaciyla Gram boyama yapılarak mikroskopta incelendi ve bakteriyoskopik bulgular kayıt edildi. Antibiyotik bulunmayan steril plastik numune kaplarına alınan süt numunelerinin, Kanlı Agar, MacConkey Agar'a ekimleri yap $11 \mathrm{~d} 1$ ve $37^{\circ} \mathrm{C}$ ' de 2-3 gün süre ile aerobik ortamda inkübe edildikten sonra üreyen koloniler bakteriyolojik testler kullanılarak identifiye edildi. Ayrıca tüm bu numunelerden Sabouraud Dextrose Agar'a ekimler yap1larak $25^{\circ} \mathrm{C}^{\prime}$ de 7-10 gün süreyle aerobik ortamda inkübe edildikten sonra Aspergillus spp., ve Candida spp. yönünden cins düzeyinde identifikasyonları araştırıldi $[15,17]$.

\section{İstatistiksel Değerlendirme}

Elde edilen değerler SPSS 15.0 programında ANOVA ile değerlendirilerek, gruplararası farkl1liklar Duncan testi ile ortaya konuldu. Korelasyon analizleri için Pearson Korelasyon uyguland1 ve $\mathrm{p}<0.05$ önem düzeyinde önemli kabul edildi.

\section{Bulgular}

Alınan süt örneklerinden hazırlanan hücre homojenatı süpernatantlarının $1 \mathrm{ml}$ 'sindeki somatik hücre say1ları ile Vitamin C ( $\mu \mathrm{g} / \mathrm{ml}$ ve $\mu \mathrm{g} / 10^{6}$ hücre $)$ düzeyleri Tablo 1'de sunuldu.

Tablo 1. Sağlıklı ve mastitisli sütlerde hücre sayıları ve Vitamin $\mathrm{C}$ düzeyleri $(\mathrm{n}=12, \mathrm{Or} \pm \mathrm{SH})$

\begin{tabular}{lccc}
\hline & $\begin{array}{c}\text { 1 ml hücre } \\
\text { süpernatantındaki } \\
\text { hücre sayısı x 1000 }\end{array}$ & $\begin{array}{c}\text { Vitamin C } \\
\boldsymbol{\mu g} / \mathbf{m l}\end{array}$ & $\begin{array}{c}\text { Vitamin C } \\
\boldsymbol{\mu g} / \mathbf{1 0}^{6} \text { hücre }\end{array}$ \\
\hline Kontrol & $247-3153$ & $1,18 \pm 0,12^{\text {a }}$ & $2,47 \pm 0,75^{\text {a }}$ \\
1. grup & $3751-7620$ & $1,31 \pm 0,16^{\text {a }}$ & $0,23 \pm 0,02^{\mathrm{b}}$ \\
2. grup & $7641-15484$ & $4,10 \pm 1,05^{\mathrm{b}}$ & $0,41 \pm 0,11^{\mathrm{b}}$ \\
3. grup & $22155-43087$ & $1,62 \pm 0,25^{\text {a }}$ & $0,06 \pm 0,01^{\mathrm{b}}$ \\
4. grup & $35507-170560$ & $5,23 \pm 1,37^{\mathrm{b}}$ & $0,07 \pm 0,02^{\mathrm{b}}$ \\
\hline p & & $*$ & $*$ \\
\hline * : p $<0,001$, a, b: Aynı sütundaki farklı harfler birbirinden istatistiki \\
açıdan farklıdır.
\end{tabular}


Süt hücre Vit C düzeyleri ile süt somatik hücre sayıları arasında pozitif bir korelasyon belirlendi ve Figür 1'de sunuldu.

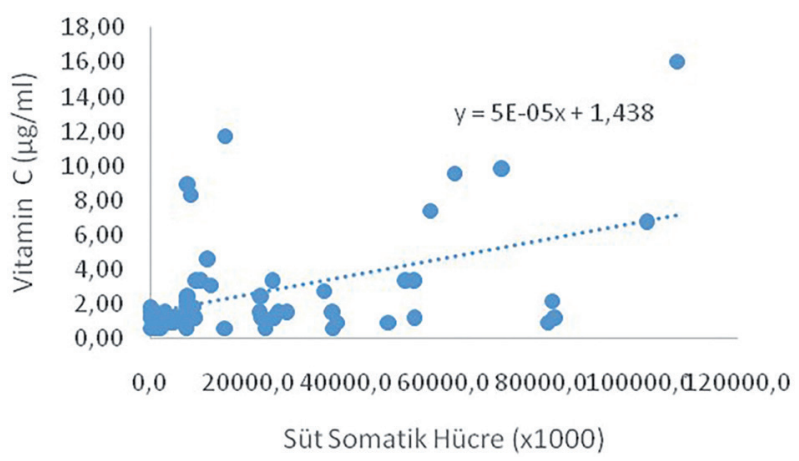

Figür 1. Süt hücrelerinde Vitamin $C$ düzeyleri ile somatik hücre sayıları arasındaki korelasyon $(\mathrm{r}=0,469$, $\mathrm{p}<0,001 \mathrm{n}=60$ )

Alınan süt örneklerinin 1 ml'sindeki somatik hücre sayıları ve süt serumundaki Vit $\mathrm{C}$ düzeyleri Tablo 2'de sunuldu.

Tablo 2. Sağlıklı ve mastitisli sütlerde Vitamin C düzeyleri $(\mathrm{n}=12, \mathrm{Ort} \pm \mathrm{SH})$

\begin{tabular}{lcc}
\hline & $\begin{array}{c}\text { 1 ml sütteki } \\
\text { hücre sayısı x 1000 }\end{array}$ & $\begin{array}{c}\text { Vitamin C } \\
\boldsymbol{\mu g} / \mathbf{m l}\end{array}$ \\
\hline Kontrol & $1-87$ & $23,78 \pm 0,55^{\text {ab }}$ \\
1. grup & $154-380$ & $26,53 \pm 0,74^{\mathrm{a}}$ \\
2. grup & $418-812$ & $25,40 \pm 2,53^{\mathrm{a}}$ \\
3. grup & $914-1928$ & $24,79 \pm 1,28^{\mathrm{a}}$ \\
4. grup & $2614-8050$ & $19,89 \pm 2,04^{\mathrm{b}}$ \\
p & & $* *$ \\
\hline * : p<0,05, a, b: Aynı sütundaki farklı harfler birbirinden istatistiki açı- \\
dan farklıdır.
\end{tabular}

Tablo 3. Mastitisli sütlerden ( $\mathrm{n}=12$, toplam 48 adet süt) izole edilen patojenler

\begin{tabular}{lc}
\hline Patojenler & Sayı (\%) \\
\hline CNS (Coagulase Negative Staphylococcus) & $20(41,6)$ \\
\hline Streptococcus spp. & $2(4,16)$ \\
Bacillus spp. & $4(8,32)$ \\
Maya & $2(4,16)$ \\
Miks Enfeksiyon & $3(6,25)$ \\
Etkenli & $31(64,58)$ \\
Etkensiz & $17(35,42)$ \\
Toplam mastitisli süt sayısı & $48(100)$ \\
\hline
\end{tabular}

KNS ve diğer patojenler arasında Vit $\mathrm{C}$ düzeyleri yönünden önemli bir farkl111k belirlenmedi $(\mathrm{p}>0.05)$.
Mastitis 4. grup Vit $\mathrm{C}$ düzeyleri diğer mastitis gruplarına $(\mathrm{p}<0.05)$ ve kontrol grubuna $(\mathrm{p}>0.05)$ göre düşük olarak belirlendi.

Süt serumlarındaki Vit C düzeyleri ile süt somatik hücreleri arasında negatif bir korelasyon belirlendi ve Figür 2'de sunuldu.

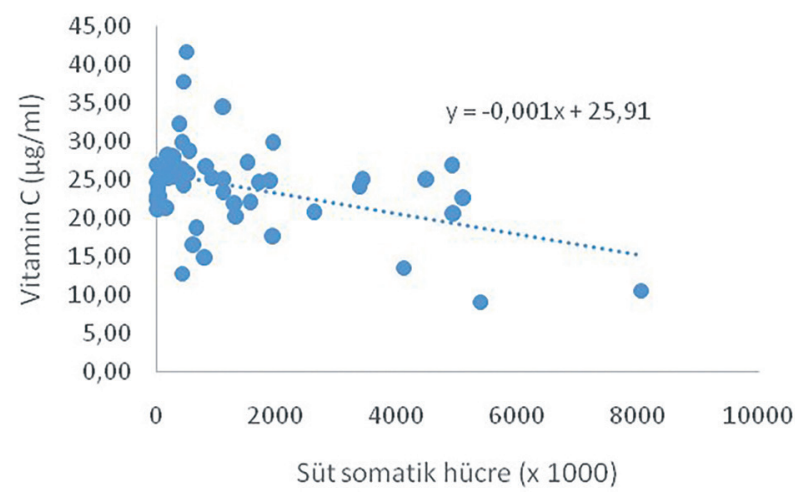

Figür 2. Süt serumunda Vitamin $C$ düzeyleri ile somatik hücre sayıları arasındaki korelasyon $(r=-0,420, p<0,01$ $\mathrm{n}=60$ )

\section{Tartışma ve Sonuç}

Mastitis süt sığırcılığının önemli problemlerinden birisini oluşturmakta ve etkilediği her bir meme lobunda süt üretimini baskılayarak ciddi ekonomik kayıplara sebep olmaktadır. Çalışmamızda süt hücrelerinin sonikasyonundan sonra elde edilen süpernatantta ve yağı ve hücreleri uzaklaştırılmış süt serumlarında Vit $\mathrm{C}$ düzeylerinin değişimi, Vit $\mathrm{C}$ ile somatik hücre sayıları arasındaki korelasyonlar belirlenmiştir. Sonuçta sağlıklı ve mastitisli sütlerin değerleri arasında önemli farklılıklar gözlenmiştir.

Sağlıklı süt serumundan elde edilen Vit $\mathrm{C}$ düzeyleri sağlıklı inek sütlerinde bildirilen düzeyler ile uyum göstermiştir [8, -25]. Çalışmamızda mastitisli sütlerdeki Vit $\mathrm{C}$ düzeylerinin yalnızca 4. grupta grupta düştüğü belirlenmiştir. Weiss ve ark. [25] Eschericia coli ile deneysel olarak mastitis oluşturulan Holstein 1rk1 ineklerde 24 saat sonra alınan süt örneklerinde Vit C düzeylerinin mastitis derecesinin artması ile birlikte önemli düzeyde düştüğünü bildirmişlerdir. Staphylococcus aureus, Streptococcus agalacia ve Echericia coli ile mastitisli ineklerde kan serumu Vit $\mathrm{C}$ düzeylerinde de bir düşüş bildirilmiştir [10]. 
Somatik hücreler meme dokusundan süte kar1şan epitel hücreleri ve yang1 veya travma durumlarında kandan meme bezine geçen lökositlerden oluşmaktadır. Süt somatik hücrelerinin $\% 75$ 'ini lökositler (lenfosit, nötrofil ve makrofaj) \%25'ini de epitel hücreleri oluşturur [19]. Meme dokusunda enfeksiyon oluştuğunda sütteki lökosit ve epitel hücre sayıları artar [4]. Sağlıklı bir memede somatik hücre sayısı 200.000 hücre /ml'den az kabul edilirken $[4,18]$, meme içi bir enfeksiyon geliştiğinde enfeksiyona karşı artan immun yanıta paralel olarak lökosit sayısı (özellikle nötrofiller) önemli ölçüde artar. Çalışmamızda süt hücrelerinde yapılan Vit $\mathrm{C}$ analizlerinde, $\mu \mathrm{g} / \mathrm{ml}$ üzerinden değerlendirildiğinde özellikle 4. grupta yüksek Vit C düzeyleri belirlenmiştir. Somatik hücre sayısının çok fazla artması (4. grupta) ile nisbi bir Vit C artışı olduğu düşünülmektedir zira $\mu \mathrm{g} / 106$ hücre üzerinden değerlendirildiğinde, mastitis derecesi arttıkça Vit C düzeylerinde azalma görülmüştür ancak istatistiki fark sadece kontrol grubu ile gözlenmiştir. Yapılan literatür taramalarında sağlıklı ve mastitisli sütlerde somatik hücre Vit $\mathrm{C}$ düzeylerinin belirlendiği bir çalışmaya rastlanılmamıştır. Ancak Weiss ve Hogan [26] lipolisakkarit (LPS) uygulaması ile oluşturulan mastitiste, süt nötrofil hücrelerini izole ederek dondurma ve çözündürme yöntemi ile hücre lizisi sağlamış ve HPLC metodu ile Vit $\mathrm{C}$ düzeylerini belirlemişlerdir. Buna göre süt nötrofillerindeki Vit C düzeylerini 80-90 pmol/10 ${ }^{6}$ hücre (yaklaşık 0,15$0,17 \mu \mathrm{g} / 106$ hücre) olarak bildirmişlerdir. Sunulan çalışmada Vit C düzeylerindeki farklılık metodolojinin farklı olmasının yanısıra hücre farklılığından da kaynaklanabilir zira elde edilen hücre pelleti tüm süt somatik hücreleri yanısıra mikroorganizma Vit $\mathrm{C}$ düzeylerini de içermektedir. LPS ile oluşturulan yang1 sirasında süt nötrofillerindeki Vit $\mathrm{C}$ düzeyleri aynı hayvanlardaki kan nötrofillerinden 3 kat daha yüksek olarak belirlenmiştir [26]. İnsan nötrofilleri aktive edildiğinde nötrofillerin ortamdan Vit $\mathrm{C}$ alımı 10-30 kata kadar artmaktadır [24]. Vitamin C'nin özellikle lökositlerdeki düzeylerinin plazma düzeylerine göre oldukça yüksek olduğu da bildirilmiştir [7]. Vitamin C'nin nötrofillerce alımı, yang1 sırasında hücre içinde meydana gelen oksidatif hasarın önlenmesi amaciyla olabilir [24]. Süt nötrofillerindeki Vit $\mathrm{C}$ düzeylerinin yüksekliği, meme yangısı sırasında sütteki nötrofillerin, kandakine göre daha fazla aktive olmasıyla ilgili olabilir [26].
Sunulan çalışmada hücre Vit C düzeyleri ve süt somatik hücre sayısı arasında pozitif bir korelasyon belirlenmiştir $(p<0,001)$. Bu bulgular araştırıcıların bulguları ile uyumlu görülmektedir. Ayrıca süt serumu Vit $\mathrm{C}$ düzeyleri ile $1 \mathrm{ml}$ sütteki somatik hücre sayıs1 arasında belirlenen negatif korelasyon da, Vit C'nin süt hücreleri tarafından ortamdan alındığını ve kullanıldığını gösterebilir. Başpınar ve ark. [3] in vitro kan lökositlerinin dış ortamdan Vit C alımının, dozun artışına bağlı olarak, arttığını, ayrıca Vit C dozu yükseldikçe, aktive edilen lökositlerin, fagositik ve mikrobisidal aktivitelerinin arttığını bildirmişlerdir. Wiess ve Hogan [26] LSD ile oluşturulan mastitis modelinde dişarıdan Vit $C$ takviyesinin süt hücrelerinde ve sütte Vit $\mathrm{C}$ düzeylerini etkilemediğini bildirmişlerdir. Diğer yandan E.coli ile oluşturulan mastitis olgusunda süt Vit $\mathrm{C}$ düzeylerinde düşüş bildirmişler ve bakteriyel ve bakteriyel olmayan mastitise memenin Vit C yanıtının farklı olduğunu düşünmüşlerdir [25].

Subklinik mastitis oluşumunda rol oynayan patojenler kontagiyöz ( $S$. aureus, $S$. agalactia ve $S$. bovis) ve çevresel (E. coli, P. aeruginosa, S. uberis, $S$. chromogenes ve diğer koagulaz negatif stafilokoklar) olarak sınıflandırılmaktadır [2]. Son yıllarda dünyada subklinik mastitis etkenleri arasinda koagulaz negatif stafilokoklar (KNS) dikkat çekmektedir. Stafilococcus aureus gibi majör patojenlerden farklı olarak KNS'ler subklinik mastitise sebep olduğundan ayrıca antibiyotiklere karşı direnç geliştirdiğinden son yıllarda birçok ülkede subklinik mastitisin önemli etkenlerinden biri olarak görülmektedir [14]. Subklinik mastitiste KNS'lerin diğer etkenlere göre daha baskın olduğu Yağc1 [27] ile Türüt ve ark. [23] tarafından bildirilmiştir. Sunulan çalışmanın mikrobiyolojik sonuçları değerlendirildiğinde de KNS'lerin oranının $(\% 41,6)$ diğer tüm patojenlere $(\% 18,9)$ göre daha yüksek olduğu görülmüştür. KNS ve diğer patojenler arasında Vit C düzeyleri yönünden önemli bir farklılık belirlenmemiştir.

Sonuç olarak subklinik mastitisin derecesi ile ilgili olarak somatik hücre sayısının $\operatorname{arttığ~} 1$, birim hücre başına düşen Vitamin $C$ ve süt serumu Vit $C$ düzeylerinin düştügüu belirlenmiş ve sütteki somatik hücre sayısı arttıkça hücrelerin Vit C ihtiyacının arttığ1 ve bu ihtiyacın süt serumundan hücre içine Vit C alımının artırılarak giderilmeye çalışıldığ 1 düşünülmüştür. 


\section{Teșekkür}

Sunulan çalışmada, Mustafa Kemal Üniversitesi Hayvan Deneyleri Yerel Etik Kurulunca (24.04.2014 tarih ve 2014-04/1 no'lu kararı) izin verilen ve Mustafa Kemal Üniversitesi Bilimsel Araştırma Projeleri tarafindan desteklenen 12161 no'lu projenin artan numuneleri kullanılmıştır.

\section{Kaynaklar}

1. Alaçam E, (1988). Meme Hastalıkları, (in) Sığır Hastalıkları, E Alaçam, M Şahal. eds. Ankara, Medisan Yayınları, p. 389-425.

2. Albenzio M, Taibi L, Muscio A, Sevi A, (2002). Prevalence and etiology of subclinical mastitis in intensively anaged flocs and related changes in the yield and quality of ewe milk. Small Rum Res. 43: 219-226.

3. Başpınar N, Baş AL, Haliloğlu S, Elmas M, Yazar E (1998) The effects of intracellular Vitamin $\mathrm{C}$ concentrations on Bovine Neutrophils Functions In vitro, Revue Med Vet. 149:931-938

4. Baştan A, (2010). İneklerde Meme Sağlığı ve Sorunları. Ankara, Kardelen Ofset Matbaacılık,1, p. 105-134.

5. Baştan A, Kaymaz M, Fındık M, Erünal N, (1997). İneklerde subklinik mastitislerin elektriksel iletkenlik, somatik hücre sayıs1 ve california mastitis test ile saptanması. A.Ü. Vet. Fak Derg. 44: 1-5.

6. Haag W, (1985). Zur methodik und praktischen Bedeutung der Vitamin C - Best immung be im Rind in Vergangenheit und Gegenwart. Inaugural Dissertation. Justus Liebig Universitaet, Giessen.

7. Haliloğlu S, Başpınar N, Baş AL, Elmas M, (1999). Sığırlarda plazma, mononükleer ve polimorf nükleer lökosit vitamin c düzeyleri ile bazı biyokimyasal parametreler arasındaki ilişkiler. Eurasian J Vet Sci. 15: 83-88.

8. Hıdıroğlu M, Ivan M, Batra TR, (1995). Concentrations of Vitamin C in plasma and milk of dairy catle. Ann Zootech. 44: 399-402.

9. Holtgrew-Bohling K,(2016). Large Animal Clinical Procedures for Veterinary Technicians. Third Edition, Elsevier Inc, Missouri, US. p:445.

10. Kleczkowski M, Klucinski W, Snaktur A, Sikora J,(2005). Concentration of ascorbic acid in the blood of cows with subclinical mastitis. Pol J Vet Sci. 8: 121-125.

11. Miller JK, Brzezinska-Slebodzinska E, Madsen FC, (1993). Oxidative stress, antioxidants, and animal function. J Dairy Sci. 76: 2812-2823.

12. Mohamed HE, Mousa HM and Beynen AC,(2005). Ascorbic acid concentrations in milk from Sudanese camelsJournal of Animal Physiology and Animal Nutrition. 89: 35-37.

13. Mutluer B, (2001). Süt İnekçiliğinde Mastitis Sempozyumu, 04-05 May1s, Burdur. Akdeniz Üniversitesi Veteriner Fakültesi Yayın Ünitesi. 2: 1.
14. Pyorala S and Taponen S, (2009). Coagulase-negative staphylococci - Emerging mastitis pathogens. Veterinary Microbiology. 134: 3-8.

15. Quinn PJ, Carter ME, Markey BK, Carter GR, (1994). Clinical Veterinary Microbiology. Mosby-Year Book Europe Limited, Lynton House, London WC1H9LB, England. s: 209-236.

16. Ramos VA, Ramos PA, Dominguez MC, (2000). The role of oxidative stress in inflammation in patients with juvenil rheumatoid arthritis. J Pediatr. 76: 125-132.

17. Schultz R, Smith PJ, Hogan KL, Love JS, (2004). Antimicrobial susceptibility of mastitis pathogens from first lactation and older cows. Veterinary Microbiology. $102: 33-42$.

18. Sharma N, (2003). Epidemiological investigation on subclinical mastitis in dairy animals: Role of vitamin $\mathrm{E}$ and selenium supplementation on its control. MVSc. Thesis, I.G.K.V.V., Raipur (C.G.) India.

19. Sharma N, (2007). Alternative approach to control intramammary infection in dairy cows. A review. Asian J Anim Vet Adv. 2: 50-62.

20. Stahl W and Sies H, (1997). Antioxidant defense: vitamins $\mathrm{E}$ and $\mathrm{C}$ and carotenoids. Diabetes, 46: 14-18.

21. Şimşek H, Aksakal M, (2006). Subklinik mastitisli ineklerde E vitamininin plazma A vitamini, beta- karoten, glutatyon peroksidaz, redükte glutatyon ve süt A vitamini düzeylerine etkisi. Fırat Üniv Sağlık Bil Derg. 20: 199-203.

22. Tekeş Y, (2006). Streptozotosin ile diabet oluşturulmuş farelerde aspirin ve E vitamininin dokularda lipid peroksidasyonu ve antioksidan sisteme etkisinin araştırılması. Yüksek Lisans Tezi, Kahramanmaraş Sütçü İmam Üniv, Fen Bil Enst, Kahramanmaraş.

23. Turut N, Ergün Y, Doğruer G, Savaşan S, Yoldaş A, (2008). Türkiye'nin Güneyindeki Süt Sığırcılığı İşletmelerinde Subklinik Mastitisin Prevalansı, Etiyolojisi ve Etkenlerin Antibiyotik Duyarlılıkları. III. Veteriner Jinekoloji Kongresi (Uluslararas1 Kat1lıml1), Antalya: 18-19.

24. Wang Y, Russo TA, Kwon S, Chanock S, Rumsey SC, (1997). Ascorbate recycling in human neutrophils: induction by bacteria, Proc Natl Acad Sci USA, 94:13816-13819.

25. Weiss WP, Hogan JS, and Smith KL, (2004). Changes in vitamin $\mathrm{C}$ concentrations in plasma and milk from dairy cows after an intramammary infusion of Escherichia coli. J. Dairy Sci. 87:32-37.

26. Weiss and WP and Hogan JS, (2007). Effects of Dietary Vitamin $\mathrm{C}$ on Neutrophil Function and Responses to Intramammary Infusion of Lipopolysaccharidein Periparturient Dairy Cows. J Dairy Sci. 90: 731-739.

27. Yağcı İP, (2008). Koyunlarda Subklinik Mastitis: Etiyoloji, Epidemiyoloji ve Tanı Yöntemleri. Kafkas Üniv Vet Fak Derg. 14: 117-122.

28. Yang JN, Wei N and Wen LF, (2012). Month-wise prevalence of subclinical mastitis in dairy cows in guangdong province, China Journal of Integrative Agriculture. 11: 166169. 